The definitive, peer-reviewed and edited version of this article is published and can be cited as

Lindsey, R. and G. Santos (2020), 'Addressing transportation and environmental externalities with economics: Are policy makers listening?', Research in Transportation Economics, Vol. 82. DOI: 10.1016/j.retrec. 2020.100872

\title{
Addressing transportation and environmental externalities with economics: Are policy makers listening?
}

\section{Robin Lindsey ${ }^{a^{*}}$ and Georgina Santos ${ }^{\mathrm{b}}$}

${ }^{*}$ Corresponding author

a Sauder School of Business, University of British Columbia, 2053 Main Mall, Vancouver, British Columbia, Canada V6T 1Z2, Robin.Lindsey@,sauder.ubc.ca

b School of Geography and Planning, Cardiff University, King Edward VII Avenue, Cardiff CF103WA, UK, SantosG@Cardiff.ac.uk

\section{Keywords:}

Traffic congestion

Pollution

Greenhouse gas emissions

JEL classification:

D62

H23

H21

\section{Q54}

Climate change

Carbon taxes

Tradable permits
Congestion pricing

Economic advice

Policymaking 


\begin{abstract}
A literature review reveals that economists have had limited success in promoting economically efficient transportation and environmental externality policies. Evidence shows that policy makers are more open to using taxes and cap-and-trade systems to combat climate change than levying tolls to manage traffic congestion. Although carbon taxes are too low, and caps on tradable permits too high, to induce significant Greenhouse Gas (GHG) emissions reductions, governments at all levels are starting to implement these instruments, and climate change is now on the international political agenda as the Paris Agreement demonstrates. By contrast, congestion charging is rare. One reason may be that the science of climate change has become virtually impossible to ignore. Another is that GHG concentrations are cumulative, and the consequences of climate change are global, irreversible and potentially catastrophic. Traffic congestion is localized and transient, and more of an inconvenience than a threat to life. Responsibility for transportation policy is also often divided across multiple levels of government. These differences may explain why the use of economic instruments has been more widespread in dealing with climate change than with congestion.
\end{abstract}

\title{
1 INTRODUCTION
}

Economists have influenced policy and practice concerning many topics in a range of fields. ${ }^{1}$ Practical problems have even motivated theoretical developments in economics (Crew and Kleindorfer, 2002). Many economists believe that the economics profession has had a major impact on the economy in general. Yet Frey (2006) claims that empirical evidence to support this is scarce, and he quotes a number of famous economists who wrote both for and against the proposition that economists have been influential. A number of scholars think that, in many cases, economists have not had as much impact as they may have anticipated, or hoped. A case in point are externalities which economists have been studying since Pigou (1920). Extensive bodies of work in environmental economics and transportation economics have accumulated since the 1950s. Politicians and policy makers, however, have been slow to adopt economists' advice despite advances in economic science, large increases in the costs of congestion and pollution, and increased recognition of the threat posed by climate change.

1 These include peak-load pricing, capital budgeting and net present value, portfolio selection, econometric forecasting, marginalist principles, Ramsey pricing, the Stand Alone Cost Test, and the use of marginal analysis in legislation (Faulhaber and Baumol, 1988); commercial innovation (Jaffe, 1989); deregulation (Crew and Kleindorfer, 2002); and privatization, central bank independence and pension reform (Kogut and Macpherson, 2011). Economists have also been leaders in formulating macroeconomic policies concerning unemployment and inflation (Appelbaum, 2019). 
In this paper we consider economists' advice regarding market-based instruments (i.e., pricing and tradable permits) to address externalities. To assess how influential economists have been, we focus on two specific cases: climate change - a global environmental externality, and traffic congestion - a local transportation externality. Road transportation creates externalities other than congestion. It is responsible for about $20 \%$ of global $\mathrm{CO}_{2}$ emissions, and it generates other pollutants (e.g., $\mathrm{CO}, \mathrm{NOX}$, volatile organic compounds and particulates) that have both local and regional impacts. For two reasons, we do not examine these environmental effects of transportation in depth. First, our review of climate-change policies is general and does not single out particular economic sectors. Second, we restrict attention to instances where economic advice has been promulgated for several decades, and also followed to some extent. This approach allows us to assess how closely practice adheres to advice. Road pricing has almost never been implemented to reduce vehicle emissions. ${ }^{2}$ To date, the main instrument has been regulation. As we note in Section 2, most advances in reducing automobile pollution have been technological rather than economic-based. Furthermore, tradable permits have not yet been used to control road transportation.

Thus, the scope of the article is limited to congestion pricing of roads, and taxes and tradable permits for greenhouse gas emissions. We ask why most existing tolls are not closely related to the marginal social costs of driving, and why congestion pricing is still uncommon. We review the literature on how economists have influenced policy making in general, as well as environmental policy specifically — where economic influence has been somewhat greater than with traffic congestion.

Such an enquiry is useful for two reasons. First, measuring transportation and environmental externalities, and deciding how best to address them, requires expertise in a number of disciplines and economics has much to offer. If economic ideas are ignored, then either externalities may go largely unchecked or valuable resources may be wasted in pursuing less effective policies (Common, 1989). Second, it is important to understand the causal chain along which economics can influence policy. What sort of models do economists use to study transportation and environmental externalities? Do economists agree on what constitutes good policy? How do they present their research findings or recommendations? Do policy makers heed the research, and do they actually use it when formulating policies? How does the public react to policy proposals? What policies eventually get implemented? Finally, are these policies later modified in a substantial way, and if so is it in a direction that accords more closely with economic reasoning? All these links in the causal chain are relevant in deciding whether and how to conduct policy-oriented research on externalities, or indeed many other subjects. We do not systematically explore every link although we touch on most of them.

\footnotetext{
${ }^{2}$ The main exception is the Ecopass cordon toll in Milan, which operated from 2008 to 2012.
} 
Assessing the influence of economics on policy is a challenging task in general, and externalities are no exception. Nevertheless, we attempt to draw a few tentative conclusions as to why economists have had only limited success. First, over the $60+$ years since concerted economic research on externalities began, substantial changes have occurred in technology, in concerns about the environment, and in what people consider to be fundamental rights. To a degree, economists have been chasing a moving target. Second, economists are not unanimous in what they consider to be the best policies. Many transportation economists adhere to the view that the price of travel should reflect marginal social costs, but some do not. Third, economists' views differ, sometimes sharply, from those of planners, policy makers, politicians and the public especially regarding equity. It is now widely acknowledged that economists need to pay more attention to the distributional effects of road pricing and other policies.

The paper is organized as follows. Section 2 recaps the instruments that economists have recommended for internalizing environmental and traffic congestion externalities. Section 3 reviews the policies currently in place. Section 4 summarizes the limited evidence on economists' influence on policy. Section 5 lists the practical difficulties in implementing environmental and transportation policies. Finally, Section 6 summarizes the findings and concludes.

\section{ECONOMIC INSTRUMENTS TO INTERNALIZE ENVIRONMENTAL AND CONGESTION EXTERNALITIES}

We begin the review with environmental externalities since the literature is more familiar to most economists, and several of the lessons carry over to transportation externalities and congestion pricing.

\subsection{Environmental externalities}

As noted below in Section 3, emissions standards are widely used to control pollution. They can take the form of an absolute standard that caps total emissions, or a ratio standard such as automobile fuel efficiency standards that limits the amount of pollution per unit of output. Environmental economists have identified four other types of instruments for addressing pollution and other environmental externalities. These instruments differ from standards and regulations in that they are market-based, thus allowing economic agents a certain degree of freedom in how to react. The four instruments are emissions taxes, input taxes, tradable permits and transferable discharge rights. 
An emissions tax is a classic example of a Pigovian tax (Baumol and Oates, 1988). When set equal to the marginal external cost of pollution at the efficient level, defined as the level of pollution at which the marginal social benefit equals the marginal social cost, the tax restores efficiency by facing polluters with the full marginal social cost of their actions. The idea is conceptually attractive although various practical difficulties can arise. To start with, and this is a problem common to all theoretically efficient instruments, there needs to be perfect information so that the marginal social costs and benefits can be estimated and the efficient level of pollution determined. Another problem is that emissions may be difficult to monitor.

An alternative to an emissions tax, proposed by Common (1977), is an input tax on the good or activity that is responsible for the emissions. Input taxes have an advantage in that outputs are generally easier to measure than emissions. However, input taxes are equivalent to emissions taxes only if emissions per unit of output are fixed (McKitrick, 2011, p.34). Input taxes are not fully efficient if products can be redesigned, or activities modified, so that they generate less pollution. For example, imposing a tax on vehicle-km driven (an activity) is only second-best if cars can be designed to be less polluting, or drivers can reduce emissions by changing speed.

Another complication with either an emissions or an input tax based on marginal external costs is that it is efficient only if first-best (i.e., socially optimal) conditions hold elsewhere in the economy. In practice, distortions usually exist in related markets. An important instance are preexisting sales, income or payroll taxes. If an emissions tax is imposed, firms generally pass on part of the cost of the tax in higher consumer prices. This reduces the real wage, which exacerbates the effects of the other taxes in discouraging work (Cropper, 2000). Due to this tax interaction effect, the second-best emissions tax is generally lower than the first-best tax, and it can even be negative. The adverse effect of a tax can be alleviated if the revenues are used to reduce other distortionary effects such as the pre-existing taxes themselves. This possibility underlies early enthusiasm for emissions taxes based on the so-called revenue recycling effect or double dividend. However, some studies have found that the tax interaction effect tends to dominate the revenue recycling effect so that the net benefits from emissions taxes are lower than what partial-equilibrium models suggest.

Coasian bargaining (Coase, 1960) between polluters and victims is sometimes proposed as a laissez-faire means of internalizing pollution externalities without recourse to government intervention. Coasian bargaining may be viable if property rights are clearly identified, and the number of parties involved is small. For example, if one firm pollutes river water that adversely affects another firm downstream, the two firms may be able to reach an efficient solution. However, bargaining is not feasible for externalities such as air pollution or climate change that involve many agents. Although not directly applicable to externalities with many agents, Coase's ground-breaking article nevertheless formed the basis of market-based quantity controls. The key 
idea was that property rights could be assigned to small "parts" of the environment. These rights would acquire a value, and could be either traded or transferred.

Transferable or tradable permits are quantity controls which target a certain level of activity (for example, emissions), assign property rights (permits) to match the targeted total quantity, and let economic agents (consumers, firms and other entities) trade these permits at an endogenously determined price. The idea was first proposed by Dales (1968). Under the restrictive assumptions of perfect information, zero transactions costs and no market power in the permits market, the number of permits distributed can be set equal to the optimum amount of emissions, and the equilibrium price of a permit will match the corrective Pigovian tax. However, as Weitzman (1974) showed, permits and taxes are not equivalent if there is uncertainty about the marginal cost of abatement, and the number of permits and the level of the tax have to be chosen in advance. If tradable permits are distributed free, rather than auctioned, they also differ from an emissions tax even without uncertainty because they do not generate revenues. This precludes the possibility of revenue recycling to reduce distortionary taxes elsewhere.

Environmental economists have argued for the introduction of either emissions taxes or tradable permits to deal with pollution, including toxic substances, air pollution, water pollution and land disposal (Hahn, 1989). They have also strongly argued for using either taxes or tradable permits to reduce $\mathrm{CO}_{2}$ emissions and slow climate change (Solomon, 1995; Tietenberg et al., 1999; Zhang, 2000). More recent models have also proposed hybrid instruments, with a combination of taxes and permits (Pizer, 2002; Goers et al., 2010).

Transferable discharge, emission, or pollution rights or licenses (Montgomery, 1972) are essentially a spin-off idea from Dales (1968). The license confers a right to emit or discharge pollutants up to a certain rate, or at a rate which will not increase the level of pollution beyond a certain point. All such licenses are freely transferable.

\subsection{Traffic congestion}

The history of economic thought on traffic congestion pricing is reviewed in Lindsey (2006), Rooney (2014) and Lehe (2019), inter alios. The idea is usually attributed to Pigou (1920) although concerted research did not begin until the 1950s. A common thread among the leading economic thinkers was that congestion should be controlled by imposing tolls based on short-run marginal costs.

An early landmark study was the "Smeed Report" (U.K. Ministry of Transport, 1964), which set out in detail principles for congestion pricing. For two reasons the Smeed Report did not precipitate any policy action. First, it was overshadowed by the "Buchanan Report" (U.K. 
Ministry of Transport, 1963), which took a planning approach that dominated thinking at the time. Indeed, opposition to the Smeed Report quickly arose (Rooney, 2014). Planners objected to economists' idea that environmental quality could be traded off against other concerns such as private travel costs. The government was concerned that motorists dislike "taxes". Road pricing was also seen to encroach on the unalienable freedom of people to drive.

Second, the authors of the Smeed Report themselves differed on the appropriate scope of the Report. Some thought that road pricing should be combined with reductions in vehicle licence fees and fuel taxes, whereas others thought that such a recommendation ventured inappropriately beyond technical aspects into politics and value judgments (Rooney, 2014). Differences among economists and the crucial importance of value judgments are discussed further in Section 4.

Congestion tolls resemble emissions taxes in some respects (Proost, 2011). Both originate from Pigou (1920) and are based on marginal social costs. The imperfect equivalence between input taxes and emissions taxes also applies to congestion. For example, imposing a tax on vehicle ownership is not an effective means of controlling congestion since an ownership tax does not vary with where, when or how much a vehicle is driven. The tax interaction and revenue recycling effects also apply to congestion tolls, and several studies have shown that the effects can be large. ${ }^{3}$

Congestion tolls and emissions taxes also differ in several ways (Proost, 2011). First, the externalities themselves differ in their potential harm. In general, pollution does not have a direct feedback effect on the amount produced of the good or activity that creates the pollution. By contrast, congestion has a negative feedback effect on travellers, who experience the delays. Indeed, the costs imposed by congestion on motorists cannot exceed their benefits since otherwise they would not drive. By contrast, the social costs of emissions can exceed the private benefits from the activity responsible for the emissions. Second, road vehicles create not only congestion, but also pollution, crashes, noise and other externalities. This complicates the design of optimal pricing schemes. Third, the potential role of tradable permits for transportation has not been explored as far as for environmental applications. There are theoretical studies of how to apply tradable permits to address different transportation externalities (Verhoef et al., 1997), including air pollution (Raux, 2004) and $\mathrm{CO}_{2}$ emissions (Albrecht, 2000, 2001; Raux and Marlot, 2005). There is a growing literature on tradable permits to control congestion ${ }^{4}$, and field experiments are now being conducted (Brands et al., 2019). However, the only operational

\footnotetext{
${ }^{3}$ See Parry and Bento (2002), Van Dender (2003), McArthur et al. (2012) and the literature review in Proost (2011).

${ }^{4}$ See Fan and Jiang (2013), Grant-Muller and Xu (2014) and Dogterom et al. (2017) for reviews.
} 
tradable permits schemes in transportation are in aviation where secondary slot trading has occurred at US airports since 1986 (Fukui, 2010).

\section{TRAFFIC CONGESTION AND CLIMATE CHANGE: THE STATE OF PLAY}

Road transportation creates a number of externalities and the costs are large. In the case of Europe, the European Commission (2019) has recently assembled estimates of the average, marginal and total costs of externalities for EU 28 member states. Total external costs for passenger and freight transportation by all modes combined amount to €987 billion in 2016 prices, or $6.6 \%$ of aggregate GDP. Road transportation is responsible for $83 \%$ of the total. The largest contributors are crashes (€279 billion), congestion (€271 billion), greenhouse gas emissions (€83 billion), and air pollution (€69 billion)..$^{5}$ The overall costs of climate change caused by global emissions from all sources are a multiple of the costs due just to road transportation. The costs of externalities from all sources worldwide are a further multiple of the total costs for Europe alone.

Since externalities are a type of market failure, some form of government intervention is needed to restore efficiency. Road travel has indeed been regulated since the early days of motoring, although few instruments are market-based. They include speed limits, one-way streets, limited traffic zones, parking restrictions, ramp metering and so on. Vehicle ownership is controlled by licensing requirements as well as various city-specific policies that impose quotas, which are allocated through auction, such as in Singapore and Shanghai, or lottery, such as in Beijing. Road space rationing has been implemented in large cities such as Mexico City, Santiago and São Paulo. A number of European cities have introduced low-emission or zero-emission zones. Temporary driving bans are occasionally imposed when pollution is especially severe. However, the most comprehensive and arguably effective policies to reduce pollution have been technological and directed at engines and fuels rather than vehicle usage. Leading instances are fuel-efficiency standards, pollution standards (e.g., Euro standards in Europe, which are becoming progressively more stringent), removal of lead and reduction of the sulfur content from motor fuels.

More recently, some countries have offered subsidies for the purchase of electric vehicles. Subsidies have been successful in increasing the share of electric vehicles - notably in Norway. However, subsidies have two well-known drawbacks. First, they are subject to free-riding by individuals who would purchase an electric vehicle without a subsidy. Second, by reducing the

\footnotetext{
${ }^{5}$ The deadweight losses from failure to internalize the externalities are considerably smaller than the total external costs, which are measured relative to a hypothetical world with no travel delays, no crashes and so on. For congestion, the estimated deadweight loss is $€ 82$ billion.
} 
cost of vehicle ownership, subsidies encourage road travel, and may therefore increase other externalities, such as traffic congestion, or air pollution from tire wear and dust. Pigovian taxation calls for discouraging activities that create negative externalities (i.e., driving internal combustion engine vehicles) rather than encouraging alternatives. ${ }^{6}$

In summary, as of 2019 most of the instruments that target traffic congestion and emissions from road transportation are command-and-control rather than price-based. Tolls are common in many countries, but in most cases, they are used to recover the construction costs of new roads and bridges. Tolls directed at reducing congestion, let alone pollution, are rare. Only five urban congestion pricing schemes exist: Singapore (introduced in 1975), London (2003), Stockholm (2006), Milan (2008) and Gothenburg (2013). Lehe (2019) provides a comprehensive review of the histories, characteristics and effects of these schemes. ${ }^{7}$ They vary significantly due to differences in city topography, the budgets and technology available when they were implemented, political constraints and other factors. They also differ with respect to how long it took to implement them since the idea was first raised.

Apart from the five urban schemes, High Occupancy Toll (HOT) lanes are the only other instance of congestion pricing. HOT lanes allow motorists driving alone to use High Occupancy Vehicle (HOV) lanes if they pay a toll. HOT lanes operate on a much smaller spatial scale than the urban schemes, and all but two HOT-lane facilities are in the United States. ${ }^{8}$ Although all existing congestion pricing schemes are designed to control congestion, they do not closely resemble the idealized congestion-pricing systems that economic theory recommends. As discussed in Section 4, the tolls charged diverge significantly from the marginal congestion externalities generated by trips.

Despite the differences in the urban schemes, they have several common features (Lehe, 2019). (1) Implementation was spurred by some atypical political development such as a granting of special authority. (2) Tolls are implemented as part of a package that includes improvements in infrastructure or services that are generally funded, in part, by revenues from the tolls. (3) Granting discounts or exemptions to broad categories of drivers or vehicles has weakened the

\footnotetext{
${ }^{6}$ A third potential drawback of subsidizing the purchase of electric vehicles is that the environmental benefits depend on how the electricity is generated. If the source is coal, electric vehicles can indirectly generate more $\mathrm{CO}_{2}$ and other pollutants than vehicles power by carbon-based fuels, as shown by, for example, Huo et al (2010) and Liu and Santos (2015a).

${ }^{7}$ Small and Gomez-Ibañez (1998) describe plans and experiments for various other types of road pricing schemes that were not implemented.

${ }^{8}$ The exceptions are Highway 1 in Israel, and a rudimentary implementation of HOT lanes on the Queen Elizabeth Way in Toronto.
} 
effects of the schemes, and some exemptions were later reduced or eliminated. (4) Increases in tolls have generally had smaller proportional effects on traffic than introduction of the tolls when the schemes were launched. We return to consider some of these features later.

Tolls can be used to price pollution, although the only example of such a toll was the Ecopass system in Milan, which operated from 2008 to 2012 until it was replaced by the Area C congestion charge. One difficulty in pricing pollution is that emissions of some pollutants are sensitive to the condition of catalytic converters, engine temperature, vehicle speeds and rate of acceleration. Conditioning tolls on these factors would be technologically challenging. Instead, the Ecopass system charged vehicles according to the Euro standards they satisfied.

Since carbon emissions vary directly with fuel consumption, fuel taxes are ideal for internalizing the climate-change externality. Fuel taxes could also internalize other externalities, such as air pollution, congestion, and crashes until more fine-tuned instruments can be implemented (Parry and Small, 2005). Indeed, recent studies have concluded that decarbonization of transportation not only yields a reduction in $\mathrm{CO}_{2}$ emissions, but a number of co-benefits as well including reductions in air pollution (Parry et al, 2015; Rao et al, 2016; High-Level Commission on Carbon Prices, 2017). However, fuel taxes in most countries do not appear to be based on transportation externalities, as Rietveld and van Woudenberg (2005) conclude. They find that the higher the share of government expenditure in GDP, the higher the fuel tax in that country. If governments designed fuel taxes with the aim of internalizing transportation externalities, rather than raising revenues to finance public expenditure, then fuel taxes would have been higher in countries with more severe externalities. However, Rietveld and van Woudenberg (2005) do not find any significant relationship between fuel taxes and externalities.

Santos (2017) also concludes that fuel taxes in Europe are not designed as efficient economic instruments to internalize congestion, safety, noise, air pollution, and climate change externalities. Gasoline taxes in a number of countries are close to the estimated optimal level, but diesel fuel is under-taxed in all 22 countries in her data set.

An important point to note is that the estimated climate-change externality from road transportation in Santos (2017,) is very small relative to other externalities when computed using the conservative Social Cost of Carbon (SCC) from the US Interagency Working Group. It is still very small when computed using the UK Department of Energy and Climate Change non-traded value of $\mathrm{CO}_{2}$, which is typically over twice as large, ${ }^{9}$ and conceptually different from the SCC.

\footnotetext{
9 The values used in both the US and the UK have been updated, and are now published in US Interagency Working Group on Social Cost of Carbon, United States Government (2016), and UK
} 
In 2009, the UK government replaced the SCC with the value of non-traded carbon (i.e., not traded under the European Union Emissions Trading System). This value is given by the abatement costs required to meet specific emissions reduction targets.

The debate over the appropriate value of the SCC, perhaps best illustrated by the discrepancy between Nordhaus and Stern (Nordhaus, 2007a), is far from settled. Estimates of the SCC vary from US $\$ 10$ up to US $\$ 1,000$ per ton of $\mathrm{CO}_{2}$ (Ricke et al., 2018). The huge range is due to many factors, including differences in the social welfare functions and distributional weights that are explicitly or implicitly used, the choice of discount rates, estimates of future emission levels, and estimates of their economic and climatological impacts (Downing et al., 2005; Tol, 2008).

More recently, the High-Level Commission on Carbon Prices (2017, p.3) concluded that carbon prices consistent with achieving the targets set in the Paris Agreement are at least US\$40 to US $\$ 80$ per ton of $\mathrm{CO}_{2}$ by 2020 . Thus, there are three approaches to pricing carbon: (a) the SCC, which measures the cost of emitting an additional ton of $\mathrm{CO}_{2}$ today and adds the cost of the damage it causes while it remains in the atmosphere, used by most scholars and governments, including the US, (b) the value of non-traded carbon, which is based on the abatement costs to meet specific emissions reduction targets, used by the UK since 2009, and (c) the carbon price that can be added to the price of dirty technologies through taxes or permits, and is consistent with the targets of the Paris Agreement, as suggested by the High-Level Commission on Carbon Prices (2017). All three approaches allow for the values to increase in real terms over time.

For the year 2020, the currently accepted values of these three approaches are US\$14.50 to US\$75 per ton of $\mathrm{CO}_{2}$ for the SCC (US Interagency Working Group on Social Cost of Carbon, United States Government, 2016, p.4, updated to 2018 dollars), US $\$ 46$ to US\$139 per ton of $\mathrm{CO}_{2}$ for the UK non-traded value (UK Department for Business, Energy \& Industrial Strategy, 2019, Table 3, converted to dollars using the IMF average exchange rate for 2018), and as already stated above, US\$40 to US\$80 per ton of $\mathrm{CO}_{2}$ for the Paris targets consistent carbon price (High-Level Commission on Carbon Prices, 2017).

In many cases, the price differential between dirty and clean technologies is still large. One such example is battery electric vehicles (BEVs) versus internal combustion engine vehicles (ICEVs). Despite vehicle operating cost savings, the life cycle cost of ownership is higher for BEVs than ICEVs. ${ }^{10}$ The social costs are also higher even when $\mathrm{CO}_{2}$ emissions are taken into account in the

Department for Business, Energy \& Industrial Strategy (2019). The gap between the two values remains roughly the same.

${ }^{10}$ The battery adds a significant premium to the purchase cost of a BEV. Nevertheless, battery technology is improving and scale economies are likely to drive manufacturing costs down. Moreover, once batteries 
calculations using the highest estimates outlined above (Liu and Santos, 2015b). Policies aimed at changing the relative costs of ownership must therefore be grounded on environmental targets rather than on economic efficiency grounds.

In contrast with transportation policies, some instruments that target Greenhouse Gas (GHG) emissions are market-based instruments, including tradable permits and taxes. The World Bank Group (2019) lists all the countries, provinces and regions that have a carbon tax, and the year when it was first introduced. ${ }^{11}$ It also lists all cap-and-trade schemes for $\mathrm{CO}_{2}$ emissions. ${ }^{12}$ The taxes in place probably do not match the marginal external cost of emissions at the efficient level of emissions. The caps of the cap-and-trade schemes probably do not equate marginal social benefits with the marginal social costs, either. Nevertheless, the design of these policies is inspired by the work of economists.

An intriguing feature is that policy makers seem to be more open to introducing economic instruments to reduce GHG emissions than to reduce traffic congestion. We discuss potential reasons for this in Section 4.

have reached the end of their lives for vehicle use, they can be recycled to recover materials to make new batteries. Old batteries can also be used for energy storage. The gap in life-cycle costs is expected to narrow, and eventually reverse.

${ }^{11}$ The carbon taxes in place at the time of writing this article, excluding any taxes that were repealed or terminated, are Finland (1990), Poland (1990), Norway (1991), Sweden (1991), Denmark (1992), Slovenia (1996), Estonia (2000), Latvia (2004), Switzerland (2008), Liechtenstein (2008) British Columbia, Canada (2008), Iceland (2010), Ireland (2010), Ukraine (2011), Japan (2012), France (2014), Mexico (2014), Spain (2014), Portugal (2015), Chile (2017), Colombia (2017), Argentina (2018), Canada (2019), Singapore (2019), Newfoundland and Labrador, Canada (2019), Prince Edward Island, Canada (2019), and South Africa (2019).

12 The cap-and-trade systems in operation at the time of writing this article, excluding any that were repealed or terminated, are European Union Emissions Trading Scheme (2005), Alberta Carbon Competitiveness Incentive Regulation (2018), which replaced the Specified Gas Emitters Regulation (2007), Switzerland ETS (2008), New Zealand ETS (2008), Regional Greenhouse Gas Initiative in the states of Connecticut, Delaware, Maine, Maryland, Massachusetts, New Hampshire, New York, Rhode Island, and Vermont in the United States (2009), Tokyo, Japan Cap and Trade (2010), Saitama, Japan ETS (2011), California Cap and Trade (2012), Québec Cap and Trade (2013), Kazakhstan ETS (2013), Korea ETS (2015), Massachusetts ETS (2018), and Nova Scotia Cap and Trade (2019). Importantly, China is set to implement a national Emission Trading System in 2020. 


\section{ECONOMISTS' INFLUENCE ON POLICY}

\subsection{Challenges in assessing the influence of economists}

It is clear that traffic congestion and climate change externalities are not addressed as economic theory prescribes. Typically, market-based instruments are either implemented in ways inconsistent with the theory, or not implemented at all. Nevertheless, it is premature to conclude that economists have had little influence. Various challenges arise in assessing economists' impact on transportation and environmental policies, or indeed policies on many other matters. In this section we review some of the major challenges discussed by Frey (2006) and other scholars.

Missing evidence. Economists may submit reports to officials, and have conversations with them, that remain confidential. Any information that does enter the public record is unlikely to be representative, and thus does not offer an unbiased view of what economists have accomplished or attempted to accomplish.

What is a policy outcome? The outcome of a policy may not be obvious. It could be the introduction of a readily-identified congestion charge, pollution tax or tradable permit system. But it could also be something less obvious such as reorganization of a government department that aligns employees' incentives more closely with the adoption of instruments that target externalities efficiently.

Time lags. Considerable time may elapse from when economists first proposed a policy to when it was implemented. This was clearly true of the London and Stockholm congestion pricing schemes, the use of tradable permits to control pollution, and international agreements to combat climate change.

Multiple potential causes. Policy outcomes may be driven by many factors. It can be difficult to distinguish the contribution of economists from the rest (Markoff and Montecinos, 1993).

The direction of causality may be unclear. While economic science can influence public policy, the reverse is also true. Kogut and Macpherson (2011) observe that a national disposition toward liberal policies could lead to their adoption while simultaneously boosting the number of economists trained at US institutions who advocate such policies. If so, it is the country's attitude that drives the policy rather than the economists.

Is the number of economists a sign of their importance? Baumol (2000) remarks on growth in the number of US government employees with graduate degrees in economics, and conjectures that this has led to an increasing receptivity to their ideas. Markoff and Montecinos (1993), however, argue that economists may not be hired to provide original advice, but rather to protect senior 
officials from criticism by other economists. If so, economists may play more of a defensive than proactive role in policy formulation and implementation.

What counts as policy advice? Science distinguishes between invention (i.e., the generation of new ideas) and innovation (i.e., the process of putting new ideas into practice). Faulhaber and Baumol (1988) identify four categories of contributions in which: (a) economists provided the actual invention; (b) economists helped in the innovation process; (c) economists derived a formula for something introduced by others in a different form (e.g., peak-load pricing); and (d) economists disseminated the ideas of others (e.g., marginal analysis). Congestion pricing combines elements of peak-load pricing (c) and marginal analysis (d). Thus, one could argue that economists did not invent the idea of congestion pricing. Nevertheless, it is clear that they have advocated it and deserve some credit for the (few) instances in which it has been adopted.

Are economists for ideas or against them? Economists often argue in favour of policies. However, they may also oppose what they consider to be bad policies or "major blunders" (Frey, 2006, p. 306). Interestingly, after concluding that the net benefits from congestion tolls may not be very large, Calfee and Winston (1998, pp. 96-97) assert that "policymakers should still pursue the policy, if only to head off other - very costly and far worse — approaches to reducing congestion."

Differences of opinion among economists. As noted in Section 2 regarding the Smeed Report, economists sometimes disagree with each other. Systematic differences have been identified between American and European economists (Frey and Eichenberger, 1992). Differences between economists with respect to preferences for taxes versus regulations for controlling emissions have also been documented by country of residence, employment and ideology (Frey et al., 1985). Common (1989) further claims that economists in the public sector prefer regulation, and suggests several possible reasons. ${ }^{13}$

\subsection{Policy in general}

In a comprehensive review, Nelson (1987) describes and evaluates the role of economists in public policy. On the one hand, economists perceive themselves as professionals qualified to help in the governing process, preferably without getting involved in politics and without making value, subjective or normative judgements. On the other hand, the more "effective" economists working in government tend to adjust policies to make them acceptable, be it in terms of property rights, personal liberties or public notions of fairness. On the basis of that, Nelson (1987, p.51) concludes that economists are likely to have more influence when they set their

\footnotetext{
${ }^{13}$ Commons (1989) argues that public-sector economists may be more aware of political considerations and practical difficulties in implementing economic instruments. In addition, they may act out of selfinterest and even favour inefficient instruments because this will create more government jobs for economists.
} 
research and recommendations in a "historical and institutional context, by showing awareness of political factors" and introducing these factors in their analyses. Nelson's (1987) views are echoed by others: economists should exercise "common sense, judgment and wisdom" (Markoff and Montecinos, 1993, p.48), and they should offer "second best" advice that will be accepted by policy makers (Jones and Cullis, 1993, p.64).

In the decades that have passed since the publication of those papers, economists have become more prone to including - and even modelling — practical policy recommendations that can be used by decision makers. Yet, there is no guarantee that economists' advice will be put to good use (March, 1994). Policy makers may ask for information that they do not use or choose to ignore. They may make decisions without having the relevant information, only to gather the information afterwards in the hope that it will support their decisions. ${ }^{14}$ Economists are also partly to blame for their lack of influence. Academic economists generally spend most of their time writing for each other, rather than policy makers or the public, and technical details and jargon may obscure basic insights that are useful for informing policy (Coyle, 2019).

\subsection{Environmental policy}

The history of economic policy advice in the environmental arena during the 1970s and 1980s largely mirrors the broader assessment summarized above. By the 1970s, most economists agreed that pollution charges are the most efficient instrument to preserve air and water quality. Yet, the idea was ignored due to skepticism toward economists who would have had to plan and help administer the charges (Nelson, 1987, pp. 68-71).

The initial enthusiasm among economists for pollution taxes overlooked the potential for tradable permits, proposed by Dales (1968). Tradable permits promised similar efficiency gains as taxes, but differed on distributional and ideological grounds. The distributional effects differ because polluters pay a tax on all emissions they generate, whereas they do not pay with permits if permits are allocated free of charge. Consequently, industry tends to favour permits over taxes, especially — and sometimes only — if the initial allocation is free. Ideological differences between the two instruments also exist as far as property rights (Nelson, 1987). An emissions tax effectively grants environmental property rights to the government, which then allows private entities to use the environment as a repository for emissions in return for a fee. In contrast, a permit grants to a private entity ownership of a limited "part" of the environment for an amount of time stipulated by the permit. The environment effectively becomes private, rather than public, property: a distinction that appeals to libertarians.

\footnotetext{
${ }^{14}$ Sager and Ravlum (2005) find evidence consistent with these claims from interviews with members of the Norwegian national assembly's Standing Committee in Transport and Communications regarding their use of results from models evaluating road and transportation projects.
} 
As economists became more familiar with the strengths of tradable permits, some came to favour permits over taxes while others retained a preference for taxes. This difference of opinion among economists may have weakened their credibility with legislatures and the public (Hanley et al., 1990). Nevertheless, during the late 1970s and 1980s economic ideas gradually gained influence with policy makers. ${ }^{15}$ Some important taxes introduced in the United States in that period include: (a) the gas guzzler tax implemented in 1978, linked to the fuel economy rating of automobiles by the Environmental Protection Agency (EPA); (b) the excise tax on hazardous chemicals, implemented in 1980 to fund the EPA's hazardous waste site clean-up program; (c) the additional excise tax on petroleum and petroleum products to fund the Oil Spill Liability Trust Fund, implemented in 1989, following the Exxon Valdez oil spill; and (d) the excise tax on ozone-depleting chemicals, with the goal of reducing the use of chlorofluorocarbons (Barthold, 1994).

Over the 1970s, 1980s and 1990s, a number of trading programs were also implemented in the United States. These included the EPA Emissions Trading programs implemented in the late 1970s; the Lead Trading program for petrol implemented in the 1980s; the Acid Rain program for electric industry sulfur dioxide (SO2) emissions and the Los Angeles air basin programs for nitrogen oxides (NOx) and SO2 emissions, implemented in the 1990s; the federal mobile source averaging, banking and trading programs implemented in the early 1990s; and the Northeast NOx Budget trading program, implemented in the late 1990s (Tietenberg et al., 1999; Ellerman and Harrison, 2003).

While taxes and tradable permits eventually gained acceptance from policy makers, the instruments were rarely implemented in their "textbook form" (Hahn, 1989, p.107). Emissions taxes were phased in gradually, and their main role was seen as raising revenues to subsidize abatement efforts rather than reducing emissions directly. Tradable permits were incorporated into existing permits and standards systems, rather than started from scratch. Furthermore, existing emitters were usually given a choice between adopting the tradable permits and continuing to meet standards as before. New sources were not always granted this choice, thereby undercutting the potential of tradable permits to equalize marginal abatement costs from all sources.

\section{The Case of Climate Change}

During the 1980s, global data on the climate was accumulating and drawing growing attention. We devote the balance of this section to climate change not only because it is perhaps the most

\footnotetext{
${ }^{15}$ As McCarthy (2019) notes, economic research on the benefits of environmental improvements was spurred by a 1981 presidential executive order requiring benefit-cost analysis of all economically significant regulations. In this instance, policy appears to have driven research rather than the reverse.
} 
pressing challenge of our time, but also because it illustrates how economists have influenced policies at a global level.

By the late 1980s, convincing evidence had accumulated that the average temperature of the Earth was increasing, and that this increase was driven by a growing concentration of GHG in the atmosphere. The main GHG was identified as $\mathrm{CO}_{2}$ produced through the combustion of fossil fuels. During the 1990s and early 2000s, modest carbon taxes were introduced in a number of countries, including Finland, Poland, Norway, Sweden, Denmark, Slovenia, and Estonia (World Bank Group, 2019). However, in the absence of a global agreement on combating climate change, countries had little incentive to act, especially when the scientific evidence on the rate of climate change was not yet well established.

The Kyoto Protocol (United Nations, 1998) was an attempt to reach a global agreement, designed under the United Nations Framework Convention on Climate Change (United Nations, 1992). Yet, some countries did not ratify it and others pulled out. The Protocol ended up covering only about $14 \%$ of the world's GHG emissions (European Parliament, 2015) and had a very limited impact. Nonetheless, it was within the Kyoto Protocol that the European Union Emissions Trading Scheme was implemented in 2005, although the caps were never stringent enough, and the price of the permits has languished under $€ 10$ (\$11) for much of the time.

One important difference between the early 2000s and more recent years is that the science of climate change has advanced substantially (see, for example, Intergovernmental Panel on Climate Change, 2018a). Probably thanks to this, the first global agreement was finally reached in Paris in December 2015 (United Nations, 2015). The Paris Agreement established a legal and institutional framework for policy makers to act on climate change. The number of countries and provinces that have now introduced market-based economic instruments to reduce GHG emissions is on the rise, as the lists in Section 3 corroborate. However, carbon prices are still below the levels necessary to trigger the required reductions in emissions (High-Level Commission on Carbon Prices, 2017; Intergovernmental Panel on Climate Change, 2018b). In fact, there are concerns that the carbon prices required may be higher than those generally accepted by the scientific community (Liu and Santos, 2015b). Moreover, as discussed in Section 5 , environmental policies still face implementation barriers - in large part due to public opposition.

\subsection{Congestion pricing}

As discussed in Section 3, traffic congestion and climate change are both costly externalities. However, traffic congestion is less critical than climate change in at least three ways. First, congestion is localized spatially and temporally. It occurs mainly in larger cities and at peak hours of the day. Climate change, by contrast, is global, progressive and essentially permanent 
since greenhouse gases persist in the atmosphere for long periods of time. Second, as noted above, traffic congestion is self-limiting since the total cost of driving cannot exceed the total benefits, whereas the social costs of emissions can greatly exceed the private benefits. Third and related, congestion is consensual insofar as motorists choose to drive in the knowledge that they will encounter delays. If they expect congestion to be severe, they can opt to drive at another time, take another mode of transport or not travel. Climate change, in contrast, cannot be avoided. ${ }^{16}$ These differences provide one explanation for why governments have been more open to using economic instruments to combat climate change than to using tolls to alleviate congestion.

Another explanation for the dearth of tolls are the many difficulties in implementing marginalcost pricing on roads. ${ }^{17}$ Some of the complications are reviewed in Section 5. A third explanation is that economists have differed in their enthusiasm for congestion pricing. Lindsey (2006) reviews their attitudes towards road pricing in general. ${ }^{18}$ Most economists agree that tolling roads to reduce congestion is a good idea, at least in principle. But they disagree on many details such as how to set tolls, what to do with the revenues and whether to compensate losers. Some economists have advocated that tolls be based on average, rather than marginal, costs in order to cover the capital costs of roads.

In the event, urban congestion pricing has only been implemented in five cities (see Section 2). The schemes do not follow the principles of marginal social cost pricing — at least in its pure form, just like the taxes and cap-and-trade programs designed to reduce $\mathrm{CO}_{2}$ emissions do not follow them either. The London Congestion Charge and Area $\mathrm{C}$ in Milan are zonal schemes whereby drivers pay a charge if they cross the boundary of the zone, or travel within it. The charges are paid only once per day, and do not vary by time of day. The zones also enclose only a small fraction of the cities. The congestion charges in Stockholm and Gothenburg are cordon tolls rather than zonal schemes. Drivers pay when they cross the cordons in and out, but not for traveling inside. However, a charge is levied for each crossing up to a daily maximum. The cordons also surround the cities so that they intercept a larger fraction of traffic than in London

\footnotetext{
${ }^{16}$ Mitigation, and even migration, are possible to avoid the most severe consequences of climate change, but they are also quite costly. Moreover, future generations have no say about current policies, but will be affected by climate change.

${ }^{17}$ Various studies have enumerated the barriers to implementation. See, for example, Jones (1998), de Palma et al. (2006), Lindsey (2006, pp. 323-332) and Verhoef et al. (2008).

${ }^{18}$ Defined broadly, road pricing includes any form of direct user charges such as tolls and area licenses, charges on any form of motorized transport, and charges for any purpose including paying for the construction costs of roads, or raising revenue to fund general expenditures.
} 
or Milan. Except for Singapore, all the schemes have featured discounts or exemptions for various categories of drivers and vehicles.

Singapore's Electronic Road Pricing is the most sophisticated of the five schemes. It comprises charges on expressways, arterial roads and three small cordons. Charges vary by facility, vehicle size and time of day. They are also reviewed every three months, and adjusted if necessary to achieve target speeds.

Despite their limitations, all five urban schemes have survived. Cost-benefit studies have been done for all the schemes except Singapore, with positive findings in each case. ${ }^{19}$ All the schemes have undergone changes, including toll levels and the set of road links that are tolled. Exemptions and discounts have generally been reduced. In most instances the changes appear to have improved efficiency, but it is difficult to assess whether economists were instrumental in making the changes.

\section{PRACTICAL DIFFICULTIES IN IMPLEMENTING ENVIRONMENTAL AND TRANSPORTATION POLICIES}

\subsection{Complexity in designing efficient systems}

The complexities of deriving economically efficient congestion tolls were appreciated early on by the authors of the Smeed Report, as well as by the designers of the London Congestion Charge (Richards, 2006). Calculating the marginal social cost of travel is not a trivial task even for a single road link under steady-state conditions. It requires traffic-engineering information about how speed varies with flow, information on the elasticity of demand, and information on the distribution of value of time in the potential driving population. Extending consideration to networks of links, heterogeneous vehicle types, traffic-flow dynamics, unpredictable fluctuations in demand and capacity, and so on complicates the problem considerably. Given the practical impossibility of pricing all travel precisely at marginal social cost, the analysis is necessarily second-best. Complex rules apply when only some links can be tolled (Verhoef et al., 1996; Verhoef, 2002). As noted earlier, distortions elsewhere in the economy should be taken into account along with the resultant tax interaction and revenue recycling effects. Pricing pollution and other transportation externalities complicates things even further. Additional measures such as reallocation of road space, changes in parking fees and investments in public transit may be warranted to offset any adverse effects of tolls or overcome opposition to tolls (Feitelson, 2003).

\footnotetext{
${ }^{19}$ See Santos and Shaffer (2004), Santos and Fraser (2006), Santos (2008) for London, Eliasson (2009) for Stockholm, Rotaris et al. (2010) and Danielis et al. (2012) for Milan, and West and Börjesson (2020) for Gothenburg.
} 
Engineers and economists alike enjoy tackling difficult problems, and their professional reputations may depend on doing so in sophisticated ways (Stiglitz, 1998; Arnott et al., 2005, p.188). Yet, even if a tolling scheme that approaches full efficiency could be developed, it is doubtful that it would be desirable. Travelers would have difficulty adapting to a complex system, and rather than trying to fully optimize their travel plans they would likely resort to rules of thumb. If so, a simpler system that is easier to understand may actually be more efficient overall than a complex one.

The complexity of designing efficient instruments to reduce GHG emissions is even greater than for alleviating congestion as far as estimating marginal benefits and marginal costs. Determining the level of optimal emissions reductions is very difficult and controversial (Nordhaus, 2007b). In addition to the climate and socio-economic uncertainties linked to the problem, it is not even clear whether policies should be harmonized. For example, a harmonized carbon tax (Nordhaus, 2007b) can be justified on the grounds that a ton of $\mathrm{CO}_{2}$ has the same effect on the climate regardless of where it is emitted. However, countries differ in their contributions to $\mathrm{CO}_{2}$ emissions, the damages they suffer from climate change (Ricke et al., 2018), the marginal costs they incur from reducing emissions, and their abilities to finance abatement efforts. These differences can be used to argue on various grounds for differential carbon taxes. Interestingly, Ricke et al. (2018) find that China, the United States and India are the countries with both the highest emissions and the highest total estimated damages from climate change. Higher carbon taxes could perhaps be justified in those countries.

\subsection{Excessive reliance on marginal-cost pricing}

As envisaged by Pigou (1920) and many economists thereafter, congestion tolls and carbon taxes should be based on marginal social costs. Yet, as Blaug (1985, p.25) notes, the principle of marginal-cost pricing rests on the criterion of Pareto efficiency whereby benefits and costs are measured relative to the status quo. The distribution of income and welfare is implicitly taken as given. Various scholars have objected to this exclusive focus on efficiency. Bromley (1990), for example, argues that production cannot be separated from distribution; and Hamilton (1992, p.62) remarks that when economists ignore distributional impacts they lose credibility. Jones and Cullis (1993) make similar arguments. Shiller (2013) notes that economics is not the discovery of fundamentals, but instead needs to focus on policy, and "much that is not science comes into play". Explicit or implicit value judgments are thus unavoidable.

\subsection{Near impossibility of Pareto Improvements}

Any road pricing or carbon tax program is almost bound to make some individuals worse off. It is natural to ask whether the winners can compensate the losers so that an actual (rather than merely a potential) Pareto Improvement can be achieved. To some extent, compensation can be 
effected by dedicating (i.e., earmarking or hypothecating) revenues from a toll or tax in ways that benefit potential losers. Economists differ in their attitudes toward dedication of congestion toll revenues (Lindsey, 2006). Some are opposed because it reduces budgetary flexibility. Some favour dedication if other charges can be reduced to maintain budget neutrality. Still others support dedicating revenues to specific goods or services such as public transit, in part because it offers a reliable stream of money to fund them. This diversity of views among economists may have undermined their credibility in advocating for congestion pricing, just as their differing preferences for emissions taxes and tradable permits may have weakened their influence on environmental policy. In the event, dedication has been a feature of all existing congestion pricing schemes except for Singapore. Dedication has been part of most proposed schemes as well.

Dedication of revenues can also be adopted with a carbon tax. One possibility is to implement lump-sum transfers, which are progressive because they amount to a greater percentage of income for poorer households. Lump-sum transfers have recently been adopted for the federal carbon tax in Canada. Governments can also compensate specific sub-groups (typically lowerincome households) that are likely to be negatively affected by the carbon tax. Carattini et al. (2018) call this social cushioning, and point out that it is also progressive because tax rebates to poorer households can be more generous.

Existing policy for allocating carbon tax revenue is diverse. Carl and Fedor (2016) analyze public revenue generated from carbon taxes and cap-and-trade systems across 40 countries and another 16 states or provinces around the world. They find that $70 \%$ of cap-and-trade revenues are not used for any rebates, but instead dedicated to "green spending" such as energy efficiency or renewable energy. They also find that $44 \%$ of carbon tax revenues are returned to corporate or individual taxpayers through paired tax cuts or direct rebates, and $28 \%$ are used in general funds. When revenues are returned to individual taxpayers via income-tax rate reductions, the reductions typically focus on lower-income groups and hence are progressive.

This range of practice indicates that allocating the revenues from a toll or carbon tax in a suitable way provides some scope to compensate losers. Nevertheless, the prospect of achieving a Pareto Improvement is slim to none for a toll, a carbon tax, or indeed any type of policy (Stiglitz, 1998). As Rietveld (2003) explains in the context of transportation policies, there are many obstacles to compensation. If revenues are dedicated, administration and transaction costs will eat up some fraction of the transfer. It is difficult to determine adequate compensation, especially if the effects of the policy are unknown or hard to measure. Those who see themselves as losers have an incentive to overstate their losses. In practice, it is difficult to target compensation narrowly 
enough when there are multiple groups. ${ }^{20}$ Some individuals within a group are likely to receive too little, whereas others receive more than enough. Compensation may have adverse incentive effects, and the practice may lead to a culture of rent-seeking. Individuals may also doubt that compensation will actually be made - especially if it requires an ongoing commitment such as toll discounts or promises to maintain high-quality transit service as an alternative to driving.

\subsection{Equity and public acceptability}

Public opposition is generally considered to be the greatest barrier to congestion pricing. Early economists who studied road pricing largely ignored or dismissed equity (Lindsey, 2006). Gradually, this changed as economists realized that Potential Pareto Improvements alone were not enough to convince either policy makers or the public that tolls, unadorned, are a good idea (Lave, 1995; Jones, 1998; Rietveld and Verhoef, 1998). Equity has now been studied extensively. ${ }^{21}$

Equity can be judged from several perspectives. One is to measure the effects of candidate road pricing schemes relative to the status quo. However, the existing system of taxes and user charges is neither efficient nor fair. Drivers pay taxes to buy, register and insure their vehicles, and they pay fuel taxes, parking fees and fines for speeding and other traffic violations. Some of these costs are regressive. An alternative perspective is to compare the welfare-distributional effects of tolling with other charges such as sales taxes (Schweitzer and Taylor, 2008). Such a comparison is especially apposite if a tolling scheme is designed to be revenue neutral so that toll revenues will displace revenues from other sources.

Lack of public acceptability is also seen as one of the main barriers to carbon pricing, especially because of concerns that carbon taxes may be regressive (Carattini et al., 2018). As discussed in the previous subsection, any regressivity could be mitigated with rebates.

Two further points that relate to the acceptability of congestion pricing come from the field of psychology. One is that attitudes toward road pricing may be sensitive to terminology. The word "tax" evokes negative reactions. ${ }^{22}$ The word "charge" in the London Congestion Charge may

${ }^{20}$ Individuals can be affected along various socioeconomic and other dimensions. For example, in De Borger and Russo's (2018) model, a cordon toll has different effects: on residents living within the cordon and those living outside, on car and public transport users, on rich and poor, and on landowners and renters.

${ }^{21}$ See, for example, Schade and Schlag (2003), Ecola and Light (2009), Schaller (2010), Franklin (2013), Noordegraaf et al. (2014) and Eliasson (2016). Some authors refer to fairness rather than equity. We use the two terms interchangeably here.

${ }^{22}$ The Stockholm Congestion Tax and the Gothenburg Congestion Tax are called taxes for legal reasons. 
have been intended to convey that the toll is a fee for the privilege of driving in the charging zone, rather than a tax unaccompanied by a corresponding benefit. The term "mobility pricing" has come into vogue as an alternative for "road pricing" or "congestion pricing". It was adopted in the name of the Metro Vancouver Mobility Pricing Independent Commission. In its final report, the Commission also refers to "Decongestion Charging". This signals that tolling is intended to reduce congestion, rather than penalize motorists for contributing to it, and thus conveys a more positive message.

The second point concerns changes in attitudes. It is well established that attitudes towards congestion pricing tend to improve after implementation (Börjesson et al., 2012; Metro Vancouver Mobility Pricing Independent Commission, 2018). Various reasons have been proposed. The most direct explanation is that people discover that tolling really does reduce congestion, as well as uncertainty about travel times and pollution. A different explanation, which derives from psychology, is that people who oppose road pricing experience cognitive dissonance if tolls are introduced against their wishes. To escape their mental discord, they consciously or subconsciously develop a more positive attitude toward the tolls (Schade and Baum, 2007).

In fact, there is growing evidence that policies can affect preferences. Mattauch et al. (2018) show that if a carbon tax alters values, the optimal second-best tax differs from the conventional first-best tax. They also note that carbon tax revenues could be returned to consumers in the initial stages of a program, but once preferences have changed the revenues could be redirected to other purposes. Nearly all the literature on transportation and environmental policies has been based on standard economic theory in which preferences are taken as given. The field of behavioural economics, however, accepts that preferences can change. Economists should consider this possibility when offering advice on transportation, environmental and other policy matters.

\subsection{Government failure}

The discussion so far has treated government as a monolithic and benevolent entity. The field of public choice within economics examines the motives of politicians and public-sector officials. Among other goals, it tries to explain why governments do not always behave in ways that promote the public interest. Transportation and environmental economists have drawn on public choice theory to understand why governments have been reluctant to adopt market-based policy instruments, and why they implement seemingly inefficient schemes. Here we limit attention to three considerations. 


\section{(a) Susceptibility to lobbying}

In democracies, politicians need to be elected or re-elected to hold office. They are susceptible to lobbying by interest groups that represent potential votes and may also offer political contributions. Interest groups have lobbied against road pricing and carbon pricing. For example, according to Dilger (2009) the American Automobile Association and the American Trucking Association have opposed congestion tolls and axle-weight charges. ${ }^{23}$ During the public consultation process in the run-up to the implementation of the London Congestion Charge, business groups, freight groups and motoring organizations lobbied for discounts for alternative fuel vehicles, and commercial and delivery vehicles (Santos, 2008). Cap-and-trade, carbon taxes or any global environmental deal have typically been opposed by the oil industry, which has also, for decades, contributed large sums of money to political campaigns in the United States (see for example, Goldenberg and Bengtsson, 2016).

\section{(b) Inability to make long-term commitments}

As noted in Section 5.3, potential losers from road pricing may doubt promises that they will receive compensation. Stiglitz (1998) recounts how general aviation interests in the United States successfully opposed congestion pricing of air traffic. The federal government was unable to make a credible commitment to a permanent compensatory system (e.g., reduced takeoff and landing fees) that would appeal to these interests. ${ }^{24}$

Difficulties in making long-term commitments have also delayed progress in dealing with climate change. Following adoption of the United Nations Framework Convention on Climate Change in 1992, international negotiations over climate change policy amounted to little more than expressions of wish until 2015 when a global Agreement was finally reached in Paris.

\section{(c) Lack of coordination between governments}

Responsibility for transportation policy and control over transportation policy instruments are often divided across federal, state, provincial and/or municipal levels of government. For example, fuel taxes are usually set nationally, while local governments control public transit fares, parking fees and road tolls. Lower-level governments typically care (and, in principle, should care) only about the welfare of their own constituents, and they may be interested in using tolls and other user charges to collect revenues as well as for efficiency reasons. Particularly in

\footnotetext{
${ }^{23}$ As noted by Winston (2013, p.806).

${ }^{24}$ Even if a government can make a credible promise while it is in power, it generally cannot bind successors.
} 
metropolitan areas, this institutional fragmentation and divergence of interests can lead to various inefficiencies. Three types of inefficiency have been studied in the literature: ${ }^{25}$

- Vertical fiscal externalities. These externalities exist if governments have overlapping tax bases. Each government ignores how its choice of tax or user charge affects other governments' revenues. This tends to lead to excessive taxes, analogous to double marginalization in the private sector with vertically-related markets.

- Tax exporting. If a local government can discriminate between users, it may impose higher charges on nonresidents than residents. In effect, the burden of raising revenue is "exported" to nonresidents. This is inconsistent with marginal-cost pricing if nonresidents create the same external costs as residents.

- Tax competition. Local governments interested in collecting revenues may set low taxes and user charges to attract traffic from neighboring jurisdictions. National governments can do so too, especially in small countries with a lot of cross-border traffic. Congestion and pollution externalities may end up underpriced. Underpricing also happens with carbon pricing when countries try to attract foreign investment by promising lower or zero carbon taxes, causing so-called "carbon leakage". This danger has been alleviated by the commitments that some countries have made to reduce their emissions. Moreover, the fourth phase of the European Union Emissions Trading Scheme will prolong the free allocation of permits to economic sectors that are at the highest risk of relocating their production outside the European Union.

- Externality spill-overs. Congestion, pollution and other externalities can spread across municipal, regional, state, provincial and national borders. Local governments may ignore these effects, and set tolls and pollution taxes that are too low from a global perspective. Climate change is the epitome of an externality; it is "a result of the greatest market failure that the world has seen" (Stern, 2007). Spill-overs in the case of climate change are the essence that describes the problem. There are no boundaries to the concentrations of $\mathrm{CO}_{2}$ in the atmosphere.

- Inappropriate mandates. Government agencies with multiple responsibilities, and limited instruments to address them all effectively, may devote inadequate attention to transportation-related issues. For example, vehicle taxes in Israel are determined on the basis of macro-economic considerations rather than the environmental costs that vehicles impose (Feitelson, 2003).

\footnotetext{
${ }^{25}$ See De Borger and Proost (2012) for an insightful review of this literature.
} 
In summary, there are various reasons why governments disregard economic lessons about how to deal with externalities. They may set tolls, taxes and other user charges that are higher or lower than optimal, or as is the case in the vast majority of cases, not implement them at all.

\section{DISCUSSION AND CONCLUSIONS}

For decades, economists have promoted the use of economic instruments to address transportation and environmental externalities. While the evidence is somewhat limited and difficult to assess, it is clear that economists have been only partially successful. Their policy recommendations have often been ignored, and when they succeeded they sometimes had to persist with their arguments over extended periods, and modify or soften their proposals.

There are various reasons why economic advice sometimes does not take root. Economists may disagree on what is the best policy. Many support carbon taxes to reduce emissions, but others favour tradable permits. Opinions also differ on how to use the revenues from a carbon tax or a congestion toll. These differences may have weakened confidence in the economics profession among policy makers and the public. Especially in the early years, when transportation economics and environmental economics were new fields, economists tended to design policies based on marginal-cost pricing principles that gave exclusive attention to efficiency. Only belatedly have they come to recognize the practical impossibility of Pareto Improvements, and the necessity of considering equity and acceptability.

Policy makers can also be at fault. They may ask for economic advice to protect themselves from politicians, other policy makers or even economists. They may not understand economists' advice, or they may disregard it when more pressing political considerations come to the fore. Governments share part of the blame, too. Politicians are susceptible to lobbying from interest groups that think taxes or tolls will make them worse off. Responsibility for policy formulation and implementation may be divided among multiple levels of government, or governments in different jurisdictions, and the government bodies concerned may fail to coordinate their decisions. Finally, governments may be unable to make long-term commitments toward the implementation of policies or continuation of policies once they are in place.

As far as externalities specifically, policy makers seem to be more open to taxes and cap-andtrade systems for climate change policy than to tolls for managing traffic congestion. The reasons behind this may be linked to the inherently different characteristics of these problems. Climate change is largely a consequence of the growing concentration of greenhouse gases which can be reversed only over long periods of time. The consequences of climate change are global and potentially catastrophic. Climate change has become a very important topic in international discussions. The science of climate change has advanced considerably, and the 
increasing number of dire forecasts - as well as extreme weather events - have spurred calls for action. The Paris Agreement, which came into force in November 2016, set the legal and institutional framework, enabling governments at all levels to go ahead. Although climate change policy is still not inducing the emission reductions that are necessary to meet the Paris targets, it is at least triggering some cutbacks, partly with help from economic instruments. Rather than concluding that economists were persuasive enough to convince governments, we are inclined to see this as governments being persuaded by the scientific evidence, which led them to ratify the Paris Agreement. Only as a result of the decision to act did they take up economists' recommendations, at least to some extent.

Traffic congestion differs from climate change in several respects. It is a local, rather than global, externality so that pressure to do something about it is absent at the international level. Congestion is recurring but transient, and it would be physically possible to eliminate it immediately. It has a network dimension which makes it harder to design policies that are both efficient and acceptable. And it is mainly an inconvenience rather than a threat to life. In short, congestion does not require attention with the same urgency as climate change. The few cities where congestion charging has been implemented are particular cases where there was a strong political commitment. In Singapore and London, traffic congestion was especially severe.

The experience in London is arguably more instructive for other cities than the experience in Singapore because the democratic process in London imposed more constraints on what policies were achievable. In London, congestion was perceived as an "environmental evil" rather than a market failure (Rooney, 2004, p.650). Ken Livingstone, who ran as an independent, was elected mayor of London in 2000 with a manifesto promising to introduce congestion charging. Extensive rounds of public and stakeholder consultations took place before the London Congestion Charge went live in 2003. These consultations influenced decisions that, from an economic point of view, could (and perhaps should) have been taken on the grounds of efficiency, rather than politics. ${ }^{26}$ Discounts for monthly and annual payments were granted despite the fact that background research had determined that they would weaken the effect of tolling on driving and congestion (Richards, 2006, p. 243). A number of discounts and exemptions were provided to groups, including the extended residents' discount which applied to residents living just outside the zone boundaries who needed to enter the zone on a regular basis. The same charge was applied to lorries as cars despite differences in their contributions to congestion. And the end of the charging period was advanced from $6: 30 \mathrm{pm}$ to $6: 00 \mathrm{pm}$ so that

\footnotetext{
${ }^{26}$ On the other hand, it may be argued that a large policy decision such as the congestion charge should be influenced by political factors, namely the views of Londoners.
} 
theatres and other establishments would not lose business in the evening. ${ }^{27}$ In a nutshell, a number of compromises were made. Interestingly, Ken Livingstone was re-elected as Mayor of London in 2004; this time as a member of the Labour Party. He was followed by Boris Johnson from the Conservative Party, who was also re-elected, and then Sadiq Kahn from the Labour Party. Thus, the congestion charge has survived three mayors with different political ideas across five elections. Once in place, the Charge has endured.

The congestion pricing schemes in Singapore, Stockholm, Milan and Gothenburg also depart significantly from schemes based on microeconomic principles. One plausible reason is that marginal cost pricing might have proved "opaque to users", in contrast with alternative concepts such as level of service, used in Singapore, and on HOT lanes where charges are set to support relatively high speeds (Richards, 2006, p.270).

In conclusion, notwithstanding economists' limited success at influencing transportation and environmental policies, some of their recommendations have been adopted. Although none of the policies are first best, they may be the best that can be expected in a second-best world. Some are also operating rather successfully. Once policy makers are able to see through the initial costs, and appreciate the potential benefits that economic instruments can bring, economic advice may get a wider and accurate hearing. Transportation economists may also have something to learn from environmental economists' success at implementing climate-change policies.

\section{REFERENCES}

Albrecht, J. (2000), The diffusion of cleaner vehicles in $\mathrm{CO}_{2}$ emission trading designs, Transportation Research Part D: Transport and Environment, 5(5), 385-401.

Albrecht, J. (2001), Tradable $\mathrm{CO}_{2}$ permits for cars and trucks, Journal of Cleaner Production, $9(2), 179-189$.

Appelbaum, B. (2019), The Economists Hour, New York: Little, Brown.

Arnott, R., Rave, T., Schöb, R. (2005), Alleviating Urban Traffic Congestion, Cambridge: MIT Press.

\footnotetext{
${ }^{27}$ Malcolm Murray-Clark (director of congestion charging for TfL), speaking at the Congestion Charging Seminar, organized by the Institution of Highways and Transportation, Imperial College, London, March 19, 2003.
} 
Barthold, T. (1994), Issues in the design of environmental excise taxes, Journal of Economic Perspectives, 8(1), 133-151.

Baumol, W.J. (2000), What Marshall didn't know: On the Twentieth Century's contributions to Economics, Quarterly Journal of Economics, 115(1), 1-44.

Baumol, W., Oates, W. (1988), The Theory of Environmental Policy, Cambridge: Cambridge University Press, $2^{\text {nd }}$ edition.

Blaug, M. (1985), Marginal cost pricing: No empty box. In Public Choice, Public Finance and Public Policy: Essays in Honour of Alan Peacock, Oxford and New York: Blackwell, pp. 15-30.

Börjesson, M., Eliasson, J., Hugosson, M., Brundell-Freij, K. (2012), The Stockholm congestion charges - 5 years on. Effects, acceptability and lessons learnt, Transport Policy, 20, 1-12.

Brands, D., Verhoef, E.T., Knockaert, J., Koster, P. (2019), Tradable permits to manage urban mobility: Market design and experimental implementation, January 27, Tinbergen Institute Discussion Paper 2019-007/VIII. (https://ssrn.com/abstract=3323642 or http://dx.doi.org/10.2139/ssrn.3323642)

Bromley, D.W. (1990). The ideology of efficiency: Searching for a theory of policy analysis, Journal of Environmental Economics and Management, 19(1), 86-107.

Calfee, J., Winston, C. (1998), The value of automobile travel time: Implications for congestion policy, Journal of Public Economics, 69, 83-102.

Carattini, S., Carvalho, M., Fankhauser, S. (2018), Overcoming public resistance to carbon taxes, WIREs Climate Change, 9:e531. (https://doi.org/10.1002/wcc.531)

Carl, J., Fedor, D. (2016), Tracking global carbon revenues: A survey of carbon taxes versus cap-and-trade in the real world, Energy Policy, 96, 50-77.

Coase, R. (1960), The problem of social cost, Journal of Law and Economics, 3(1), 1-44.

Common, M.S. (1977), A note on the use of taxes to control pollution, Scandinavian Journal of Economics, 79, 345-349. 
Common, M.S. (1989), The choice of pollution control instruments: Why is so little notice taken of economists' recommendations?, Environment and Planning A: Economy and Space, 21, 12971314.

Coyle, D. (2019), The proposed 'science of progress' raises crucial economic questions, The Globe and Mail, August 14, p. B4.

Crew, M.A., Kleindorfer, P.R. (2002), Regulatory economics: Twenty years of progress?, Journal of Regulatory Economics, 21(1), 5-22

Cropper, M.L. (2000), Has economic research answered the needs of environmental policy?, Journal of Environmental Economics and Management, 39, 328-350.

Dales J. (1968), Pollution, Property and Prices, Toronto: University of Toronto Press.

Danielis, R., Rotaris, L., Marcucci, E., Massiani, J. (2012), A medium term evaluation of the Ecopass road pricing scheme in Milan: economic, environmental and transport impacts, Economics and Policy of Energy and the Environment, 2, 49-83.

De Borger, B., Proost, S. (2012), Transport policy competition between governments: A selective survey of the literature, Economics of Transportation, 1, 35-48.

De Borger, B., Russo, A. (2018), The political economy of cordon tolls, Journal of Urban Economics, 105, 133-148.

de Palma, A., Lindsey, R., Niskanen, E. (2006). Policy insights from the urban road pricing case studies, Transport Policy, 13(2), 149-161.

Dilger, R.J. (2009), Federalism Issues in Surface Transportation Policy: Past and Present, Washington, D.C.: Congressional Research Service.

Dogterom, N., Ettema, D., Dijst, M. (2017), Tradable credits for managing car travel: A review of empirical research and relevant behavioural approaches, Transport Reviews, 37(3), 322-343.

Downing, T., Anthoff, D., Butterfield, R.; Ceronsky, M.; Grubb, M.; Guo, J.; Hepburn, C.; Hope, C.; Hunt, A.; Li, A.; Markandya, A.; Moss, S.; Nyong, A.; Tol, R.; Watkiss, P. (2005), Social Cost of Carbon: A Closer Look at Uncertainty, Final Report, Stockholm Environment Institute, Oxford, November. 
(https://assets.publishing.service.gov.uk/government/uploads/system/uploads/attachment_data/fil e/243814/sei-scc-report.pdf)

Ecola, L., Light, T. (2010), Making congestion pricing equitable, Transportation Research Record, 2187, 53-59.

Eliasson, J. (2009), Cost-benefit analysis of the Stockholm congestion charging system, Transportation Research Part A: Policy and Practice, 43(4), 468-80.

Eliasson, J. (2016), Is congestion pricing fair? Consumer and citizen perspectives on equity effects, Transport Policy, 52, 1-15.

Ellerman, A.D., Harrison, Jr., D. (2003), Emissions trading in the U.S.: Experience, Lessons, and Considerations for Greenhouse Gases, Report Prepared for the Pew Center on Global Climate Change, May. (http://web.mit.edu/globalchange/www/PewCtr_MIT_Rpt_Ellerman.pdf)

European Commission (2019), Handbook on the External Costs of Transport, Version 2019. (https://ec.europa.eu/transport/sites/transport/files/studies/internalisation-handbook-isbn-978-9279-96917-1.pdf)

European Parliament (2015), At a Glance Plenary - Doha Amendment to the Kyoto Protocol. (http://www.europarl.europa.eu/EPRS/EPRS-AaG-559475-Doha-Agreement-Kyoto-ProtocolFINAL.pdf) 
Fan, W., Jiang, X. (2013), Tradable mobility permits in roadway capacity allocation: Review and appraisal, Transport Policy, 30, 132-142.

Faulhaber, G.R., Baumol, W.J. (1988), Economists as innovators: Practical products of theoretical research, Journal of Economic Literature, 26(2), 577-600.

Feitelson, E. (2003), Packaging policies to address environmental concerns. In D.A. Hensher and K.J. Button 9eds.), Handbook of Transport and the Environment. Handbooks in Transport Volume 4, Elsevier, pp. 757-769.

Franklin, J. (2013), Role of context in equity effects of congestion pricing, Transportation Research Record, 2297, 29-37.

Frey, B.S. (2006), How influential is economics? De Economist, 154(2), 295-311.

Frey, B.S., Eichenberger, R. (1992), Economics and economists: A European perspective, The American Economic Review Papers and Proceedings, 82(2), 216-220.

Frey, B.S., Schneider, F., Pommerehne, W.W. (1985), Economists' opinions on environmental policy instruments: Analysis of a survey, Journal of Environmental Economics and Management, $12,62-71$.

Fukui, H. (2010). An empirical analysis of airport slot trading in the United States. Transportation Research Part B, 44(3), 330-357.

Goers, S.R., Wagner, A.F., Wegmayr, J. (2010), New and old market-based instruments for climate change policy, Environmental Economics and Policy Studies, 12(1), 1-30.

Goldenberg, S., Bengtsson, H. (2016), Oil and gas industry has pumped millions into Republican campaigns, The Guardian, 3 March. (https://www.theguardian.com/us-news/2016/mar/03/oiland-gas-industry-has-pumped-millions-into-republican-campaigns)

Grant-Muller, S., Xu, M. (2014), The role of tradable credit schemes in road traffic congestion management, Transport Reviews, 34(2), 128-149.

Hahn, R. (1989), Economic prescriptions for environmental problems: How the patient followed the doctor's orders, Journal of Economic Perspectives, 3(2), 95-114. 
Hamilton, L.H. (1992), Economists as public policy advisers, Journal of Economic Perspectives, 6, 61-64.

Hanley, N., Hallett, S., Moffatt, I. (1990), Research Policy and Review 33. Why is more notice not taken of economists' prescriptions for the control of pollution?, Environment and Planning A, 22, 1421-1439.

High-Level Commission on Carbon Prices (2017), Report of the High-Level Commission on Carbon Prices. (https://www.carbonpricingleadership.org/highlevel-economic-commission-1)

Huo, H., Zhang, Q., Wang, M.Q., Streets, D.G., He, K. (2010), Environmental implication of electric vehicles in China. Environmental Science and Technology, 44, 4856-4861.

Intergovernmental Panel on Climate Change (2018a), Global Warming of $1.5^{\circ} \mathrm{C}$. An IPCC Special Report on the impacts of global warming of $1.5^{\circ} \mathrm{C}$ above pre-industrial levels and related global greenhouse gas emission pathways, in the context of strengthening the global response to the threat of climate change, sustainable development, and efforts to eradicate poverty [MassonDelmotte, V., P. Zhai, H.-O. Pörtner, D. Roberts, J. Skea, P.R. Shukla, A. Pirani, W. MoufoumaOkia, C. Péan, R. Pidcock, S. Connors, J.B.R. Matthews, Y. Chen, X. Zhou, M.I. Gomis, E. Lonnoy, T. Maycock, M. Tignor, and T. Waterfield (eds.)]. (https://www.ipcc.ch/site/assets/uploads/sites/2/2019/06/SR15_Full_Report_High_Res.pdf)

Intergovernmental Panel on Climate Change (2018b), Emissions Gap Report 2018. (https://www.ipcc.ch/site/assets/uploads/2018/12/UNEP-1.pdf)

Jaffe, A.B. (1989), Real effects of academic research, American Economic Review, 79(5), 957970.

Jones, P.M. (1998), Urban road pricing: Public acceptability and barriers to implementation. In Button, K.J. and E.T. Verhoef (eds.), Road Pricing, Traffic Congestion and the Environment: Issues of Efficiency and Social Feasibility, Cheltenham, UK: Edward Elgar, 263-284.

Jones, P.R., Cullis, J.G. (1993), Public choice and public policy: The vulnerability of economic advice to the interpretation of politicians, Public Choice, 75, 63-77.

Kogut, B., Macpherson, M. (2011), The mobility of economists and the diffusion of policy ideas: The influence of economics on national policies, Research Policy, 40(10), 1307-1320. 
Lave, C.A. (1995), The demand curve under road pricing and the problem of political feasibility: Author's Reply, Transportation Research Part A: Policy and Practice, 29(6), 464-465.

Lehe, L. (2019), Downtown congestion pricing in practice, Transportation Research Part C: Emerging Technologies, 100, 200-223.

Lindsey, R. (2006), Do economists reach a conclusion?, Econ Journal Watch, 3(2), 292-379. (https://econjwatch.org/articles/do-economists-reach-a-conclusion-on-road-pricing-theintellectual-history-of-an-idea)

Liu, J., Santos, G. (2015a), The plug-in hybrid electric vehicles potential for urban transport in China: The role of energy sources and utility factors, International Journal of Sustainable Transportation, 9(2), 145-157.

Liu, J., Santos, G. (2015b), Decarbonising the road transport sector: Breakeven point and consequent potential consumers' behaviour for the US case, International Journal of Sustainable Transportation, 9(3), 159-175.

March, J.G. (1994), A Primer on Decision Making: How Decisions Happen, New York: Free Press.

Markoff, J., Montecinos, V. (1993), The ubiquitous rise of economists, Journal of Public Policy, 13(1), 37-68.

Mattauch, L., Hepburn, C., Smarzynska Javorcik, B. (2018), Pigou pushes preferences: Decarbonisation and endogenous values, CESifo Working Paper No. 7404. (https://ssrn.com/abstract=3338758)

McArthur, D.P., Thorsen, I., Ubøe, J. (2012), Labour market effects in assessing the costs and benefits of road pricing, Transportation Research Part A: Policy and Practice, 46(2), 310-321.

McCarthy, G. (2019), Editorial: The role of environmental economics in U.S. environmental policy, Review of Environmental Economics and Policy, 13(2), 299-307.

McKitrick, R.R. (2011), Economic Analysis of Environmental Policy, Toronto: University of Toronto Press.

Metro Vancouver Mobility Pricing Independent Commission (2018), Phase 1 Project Update Full Report: Phase 1 Research and Engagement for the It's Time Project, Vancouver, January. 
(www.itstimemv.ca/uploads/1/0/6/9/106921821/its_time_-_phase_1_full_report_-_final__digital_version.pdf)

Montgomery, W.D. (1972), Markets and licenses and efficient pollution control programs, Journal of Economic Theory, 5, 395-418.

Nelson, R.H. (1987), The economics profession and the making of public policy, Journal of Economic Literature, 25(1), 49-91.

Noordegraaf, D.V., Annema, J.A., van Wee, B. (2014), Policy implementation lessons from six road pricing cases, Transportation Research Part A: Policy and Practice, 59, 172-191.

Nordhaus, W.D. (2007a), A review of the Stern Review on the Economics of Climate Change, Journal of Economic Literature XLV, 686-702.

Nordhaus, W.D. (2007b), To tax or not to tax: Alternative approaches to slowing global warming, Review of Environmental Economics and Policy, 1(1), 26-44.

Parry, I.W.H., Bento, A. (2002), Estimating the welfare effect of congestion taxes: The critical importance of other distortions within the transport system, Journal of Urban Economics, 51, 339-365.

Parry, I.W.H., Small, K.A. (2005), Does Britain or the United States have the right gasoline tax?, The American Economic Review, 95(4), 1276-1289.

Parry, I., Veung, C., Heine, D. (2015), How much carbon pricing is in countries' own interests? The critical role of co-benefits, Climate Change Economics 6(4), 1-26.

Pigou, A.C. (1920), The Economics of Welfare. London: Macmillan.

Pizer, W.A. (2002), Combining price and quantity controls to mitigate global climate change, Journal of Public Economics, 85(3), 409-434.

Proost, S. (2011), Theory of external costs. In: de Palma, A., R. Lindsey, E. Quinet and R. Vickerman (eds.), Handbook in Transport Economics, Cheltenham, UK and Northampton, Mass, USA: Edward Elgar, 319-340.

Rao, S., Klimont, Z., Leitao, J., Riahi, K., van Dingenen, R., Reis, L.A., Calvin, K., Dentener, F., Drouet, L., Fujimori, S., Harmsen, M., Luderer, G., Heyes, C., Strefler, J., Tavoni, M., van 
Vuuren, D.P. (2016), A multi-model assessment of the co-benefits of climate mitigation for global air quality, Environmental Research Letters 11(12). (https://iopscience.iop.org/article/10.1088/1748-9326/11/12/124013)

Raux, C. (2004), The use of transferable permits in transport policy, Transportation Research Part D: Transport and Environment, 9(3), 185-197.

Raux, C., Marlot, G. (2005), A system of tradable $\mathrm{CO}_{2}$ permits applied to fuel consumption by motorists, Transport Policy, 12(3), 255-265.

Richards, M.G. (2006), Congestion Charging in London: The Policy and the Politics, Houndsmill, Basingstoke, Hampshire and New York: Palgrave Macmillan.

Ricke, K., Drouet, L., Caldeira, K., Tavoni, M. (2018), Country-level social cost of carbon, Nature Climate Change, 8, October, 895-900.

Rietveld, P. (2003). Winners and losers in transport policy: On efficiency, equity, and compensation. In: Hensher, D.A. and K.J. Button (eds.), Handbook of Transport and the Environment. Handbooks in Transport Volume 4, Elsevier, pp. 585-601.

Rietveld, P., van Woudenberg, S. (2005), Why fuel prices differ, Energy Economics, 27(1), 7992.

Rietveld, P., Verhoef, E.T. (1998), Social feasibility of policies to reduce externalities in transport. In: Button, K.J. and E.T. Verhoef (eds.), Road Pricing, Traffic Congestion and the Environment: Issues of Efficiency and Social Feasibility, Cheltenham, UK: Edward Elgar, 285307.

Rooney, D. (2014), The political economy of congestion: Road pricing and the neoliberal project, 1952-2003, Twentieth Century British History, 25(4), 628-650.

Rotaris, L., Danielis, R., Marcucci, E., Massiani, J. (2010), The urban road pricing scheme to curb pollution in Milan, Italy: Description, impacts, and preliminary cost-benefit analysis assessment, Transportation Research Part A: Policy and Practice, 44(5), 359-75.

Sager, T., Ravlum, I-A. (2005), The political relevance of planners' analysis: The case of a parliamentary standing committee, Planning Theory, 4(1), 33-65. 
Santos, G. (2008), The London Congestion Charging Scheme, Brookings Wharton Papers on Urban Affairs 2008, pp. 177-234

Santos, G. (2017), Road fuel taxes in Europe: Do they internalise road transport externalities?, Transport Policy, 53, 120-134.

Santos, G. Fraser, G. (2006), Road Pricing: Lessons from London, Economic Policy, 21(46), 264-310.

Santos, G., Shaffer, B. (2004), Preliminary results of the London Congestion Charging Scheme, Public Works, Management and Policy, 9(2), 164-181.

Schade, J., Baum, M. (2007), Reactance or acceptance? Reactions towards the introduction of road pricing, Transportation Research A: Policy and Practice, 41, 41-48.

Schade, J., Schlag, B. (eds.) (2003), Acceptability of Transport Pricing Strategies, Amsterdam: Elsevier.

Schaller, B. (2010), New York City's congestion pricing experience and implications for road pricing acceptance in the United States, Transport Policy, 17, 266-273.

Schweitzer, L., Taylor, B.D. (2008), Just pricing: The distributional effects of congestion pricing and sales taxes, Transportation, 35(6), 797-812.

Shiller, R.J. (2013), Is Economics a Science?, Project Syndicate. (https://www.projectsyndicate.org/commentary/robert-j--shilleron-whether-he-is-a-scientist)

Small, K.A., Gomez-Ibañez, J.A. (1998), Road pricing for congestion management: The transition from theory to policy. In: Button, K.J. and E.T. Verhoef (eds.), Road Pricing, Traffic Congestion and the Environment: Issues of Efficiency and Social Feasibility, Cheltenham, UK: Edward Elgar, 213-246.

Solomon, B. (1995), Global $\mathrm{CO}_{2}$ emissions trading - early lessons from the US acid-rain program, Climatic Change, 30(1), 75-96.

Stern, N. (2007), The Economics of Climate Change: the Stern Review, Cambridge and New York: Cambridge University Press. 
Stiglitz, J.E. (1998), The private uses of public interests: Incentives and institutions, Journal of Economic Perspectives, 12(2), Spring, 3-22.

Tietenberg, T., Grubb, M., Michaelowa, A., Swift, B., Zhang, Z.X. (1999), International rules for greenhouse gas emissions trading. Defining the principles, modalities, rules and guidelines for verification, reporting and accountability, UN Conference on Trade and Development, Geneva. (https://digitallibrary.un.org/record/609354)

Tol, R. (2008), The social cost of carbon: Trends, outliers and catastrophes, Economics: The Open-Access, Open-Assessment E-Journal, 2(25), 12 August. (www.economicsejournal.org/economics/journalarticles/2008-25/)

UK Department for Business, Energy \& Industrial Strategy (2019), Data Tables 1-19: Supporting the Toolkit and the Guidance, March. (https://www.gov.uk/government/publications/valuationof-energy-use-and-greenhouse-gas-emissions-for-appraisal)

UK Ministry of Transport (1963), Traffic in Towns: A Study of the Long-Term Problems of Traffic in Urban Areas, London: H.M. Stationery Office.

UK Ministry of Transport (1964), Road Pricing: The Economic and Technical Possibilities, London: H.M. Stationery Office.

United Nations (1992), United Nations Framework Convention on Climate Change. (https://unfccc.int/resource/docs/convkp/conveng.pdf)

United Nations (1998), Kyoto Protocol to the United Nations Framework Convention on Climate Change. (https://unfccc.int/resource/docs/convkp/kpeng.pdf)

United Nations (2015), Paris Agreement. (http://unfccc.int/files/essential_background/convention/application/pdf/english_paris_agreement .pdf)

US Interagency Working Group on Social Cost of Carbon, United States Government (2016), Technical Support Document: Technical Update of the Social Cost of Carbon for Regulatory Impact Analysis Under Executive Order 12866. (www.epa.gov/sites/production/files/201612/documents/sc_co2_tsd_august_2016.pdf)

Van Dender, K. (2003), Transport taxes with multiple trip purposes, Scandinavian Journal of Economics, 105, 295-310. 
Verhoef, E.T. (2002), Second-best congestion pricing in general networks: Heuristic algorithms for finding second-best optimal toll levels and toll points, Transportation Research B: Methodological, 36(8), 707-729.

Verhoef, E.T., Nijkamp, P., Rietveld, P. (1996), Second-best congestion pricing: The case of an untolled alternative, Journal of Urban Economics, 40, 279-302.

Verhoef, E.T., Nijkamp, P., Rietveld, P. (1997), Tradeable permits: Their potential in the regulation of road transport externalities, Environment and Planning B: Planning and Design, 24(4), 527-548.

Verhoef, E.T., Lindsey, R., Niskanen, E., de Palma, A., Moilanen, P., Proost, S., Vold, A. (2018), Implementation paths for marginal-cost-based pricing in urban transport: Theoretical considerations and case study results. In: Jensen-Butler, C., B. Sloth, M.M. Larsen, B. Madsen and O.A. Nielsen (eds.), Road Pricing, the Economy and the Environment, Berlin: Springer Verlag, pp. 49-78.

Weitzman, M. (1974), Prices vs. quantities, Review of Economic Studies, 41(4), 477-491.

West, J., Börjesson, M. (2020), The Gothenburg Congestion charges: Cost-benefit analysis and distribution effects, Transportation, 47, 145-174.

Winston, C. (2013), On the performance of the U.S. transportation system: Caution ahead, Journal of Economic Literature, 51(3), 773-825.

World Bank Group (2019), State and Trends of Carbon Pricing 2019. Washington, DC: World Bank. (https://openknowledge.worldbank.org/handle/10986/31755)

Zhang, Z.X. (2000), The design and implementation of an international trading scheme for greenhouse gas emissions, Environment and Planning C: Government and Policy, 18(3), 321337. 